\title{
Using Speech Act Sets to Inform Study Abroad Instruction
}

\author{
Joseph Siegel \\ Meiji Gakuin University
}

This paper considers the use of speech act sets (SASs) to inform study abroad instruction and examine pragmatic development of English learners before and after their overseas experiences. To do so, it focuses on pre/post-study abroad oral discourse completion tasks completed by five Japanese university students who studied abroad in the US for one semester. Their spoken responses to a set of ten scenarios were video recorded, transcribed and compared to SASs, which are models of functional language use. To exemplify this approach to pragmatic assessment, the paper focuses on three SASs: apology, request, and thanking. Findings from the SAS analysis show not only pragmatic development but also identify specific aspects that teachers may wish to address during study abroad instruction. This type of informed instruction can build on students' existing ability and target pragmatic options that they may need to adopt if they are going to study abroad.

本論の目的は、留学前教育において発話行為セット (SAS) の使用を 奨励することと、留学前後における英語語用論的能力、特に発話行為の 発達を分析することにある。本研究では1学期間の米国留学を行った5 名の日本人大学生 に対して実施した口頭談話完成タスク (ODCT: oral discourse completion task) に着目した。このテストは留学前と帰国後に 実施され、10の筋書きに対する応答を録画し、書き起こして、機能的言語 使用のモデルとされるSASと比較した。中でも「謝罪」「依頼」「感謝」の 3つのSASに焦点を当て分析を行つた。その結果、発話行為に発達がみら れただけでなく、留学前教育において指導が必要とされる点が明らかに なつた。このような研究に基づいた指導は学習者が既に持っている能力 を伸ばすことができるだけでなく、特に留学の際に必要となる発話行為 に焦点を当てることができる。

W ith the increasing ease of international travel, the importance of intercultural communication, and the position of English as a lingua franca, university students from English as a foreign language (EFL) contexts are studying abroad in English as a second language (ESL) settings in increasing numbers. All of these trends will likely continue, as study abroad leads to "increased cultural capital for the individual [and] improved international relations" (Bryam \& Feng, 2006, p. 1). In Japan, the Education Ministry reports that 58,600 Japanese students studied abroad in 2010, a number the Japanese government appears motivated to double in the near future (Kameda, 2013). Given these expectations for Japan and other countries where EFL is taught, study abroad preparation courses and the development of language abilities while abroad are relevant areas in need of immediate attention from second language (L2) teachers and researchers.

Students on study abroad programs typically have opportunities to attend classes, join clubs, make friends, and interact with host families in the L2adventures that undoubtedly contribute to their L2 development. That development is often assessed by standardized receptive tests that may overlook or undervalue the pragmatic competence and output of study abroad learners in favor of skill-based multiple choice questions. Further, such tests do little to inform subsequent teaching and curriculum planning. Study abroad invariably involves interaction with people in real life (e.g., ordering food, using public transportation, etc.). Therefore, it is important to understand and monitor the pragmatic ability and progress of students in study abroad programs.

The purpose of this paper is to consider the value of speech act sets (SASs) in monitoring pragmatic development and determining students' needs for targeted instruction in study abroad preparation courses. While this paper focuses on students studying abroad, many university students do not study overseas. However, some may hope to travel abroad, live overseas short-term, and/or communicate in their L2 in other contexts. As such, pragmatic ability is also likely a necessary attribute for those students. The paper begins by discussing pragmatics as a general field within EFL/ESL education and then moves on to outline SASs. These are prototypical, move-by-move sequences that accomplish particular objectives. As such, SASs are valuable tools for examining language and strategic choices made during speech production. To exemplify this approach to language analysis, and how it can be used to inform study abroad instruction, analysis of three SASs (apologizing, requesting, and thanking) completed by five Japanese university students are highlighted. Because the number of participants involved in this project is limited, the findings and discussion in this article should be viewed as illustrative rather than comprehensive. 


\section{Pragmatic Development and Study Abroad}

Pragmatics has been defined as "the study of language from the point of view of users, especially the choices they make... and the effects their use of language has on other participants in the act of communication" (Crystal, 1997, p. 301). Two aspects of this definition should be points of emphasis for study abroad instructors and students: choice and effect. When it comes to pragmatic choice, EFL/ESL learners need to be aware of the range of linguistic and strategic options to which they can avail themselves. The linguistic options will certainly differ from their first language (L1), while the strategic alternatives in English may also vary depending on L1 and cultural background (Blum-Kulka \& Olshtain, 1984). It is important for learners to develop a repertoire of practical situation-dependent communicative choices. This is because study abroad students need to interact successfully in diverse contexts and new cultures with speakers ranging in age, gender, social class, and status (Ishihara \& Cohen, 2010; Kinginger \& Farrell, 2004).

In terms of effect, learners need to realize and be introduced to the potential consequences of using these different linguistic options in certain situations and contexts. For instance, speaking to a friend in the cafeteria about a poor test result may require different language and strategies than speaking about the same topic to an instructor who administered the test. Such situations require speakers to consider options and select among alternatives to produce contextually-appropriate speech (Kasper \& Rose, 2002). The capacity to operate within pragmatic norms, which are a "range of tendencies or conventions for pragmatic language use that are ... typically or generally preferred in the L2 community" (Ishihara \& Cohen, 2010, p. 13), is important in such scenarios.

Violation of these norms may lead to unintended consequences and unequal treatment for the speaker. On the other hand, cultured choices and appropriate interaction with different sub-groups will potentially lead to more positive experiences and increased L2 motivation for learners. Based on this pragmatic line of thinking, teachers involved in study abroad support programs may consider the following questions: Are learners equipped with the linguistic and strategic range to appropriately adjust their output depending on different situations? Do they understand the potential impact of choosing one phrase or strategy over another?

Given the importance of pragmatic competence to productive and successful study abroad experiences, one might expect a reasonable amount of classroom time devoted to pragmatic choice and effect. The typical classroom context in Japan, like many other EFL/ESL environments, may struggle to prime learners with extensive and appropriate pragmatic abilities to thrive in interactions beyond the classroom. That is, pragmatic development may be underrepresented in classes and/or in teaching materials. While the classroom context may be suitable for targeting grammar or syntax, it is often largely inadequate for pragmatic and sociolinguistic development (Fraser, 2010; Kasper \& Rose, 2002). According to Kinginger and Farrell (2004, p. 19), study abroad can serve as a useful "complement [to classroom instruction, as it potentially links] linguistic and pragmatic features."

Study abroad experiences can compensate for the lack of pragmatic attention in typical L2 classrooms and are said to provide ample opportunities to gain meaningful pragmatic perception and experience (Taguchi, 2011). Taguchi (2014, p. 4) notes that study abroad benefits learners by "[developing] their sociopragmatic sensitivity [so that learners] come to understand that their linguistic choices are guided by the contextual factors of the circumstances. [Moreover] their choices have a direct consequence on the outcome of interaction and interpersonal relationships". In other words, students need to be aware of their options and the consequences that can come from appropriate and inappropriate choices. Even though L1 norms for language functions may differ from the L2, learners embarking on study abroad will benefit from familiarity with $\mathrm{L} 2$ speech act norms. Given this importance, it may be advantageous for educators to examine students' pragmatic abilities prior to and following study abroad. Such examination would allow teachers to understand how to prepare learners. In addition, it would provide them with data on how pragmatic competence evolves during the students' time abroad.

\section{Speech Act Sets}

While pragmatics is a broad area within linguistics, much related research has involved speech acts performed by learners, and the linguistic and strategic choices they make (Mitchell, Myles, \& Marsden, 2013). A speech act entails the "communicative function associated with a single utterance, e.g., requesting, advising, or warning" (Mitchell, Myles \& Marsden, 2013, p. 305). That is, speech acts succinctly describe what speakers are doing with language and thus, examinations of speech acts have been valuable in identifying and differentiating the steps and stages of functional communication.

In an effort to advance pragmatic studies through a speech act perspective, the notion of speech act 
sets (SASs) has been promoted in recent literature (Ishihara \& Cohen, 2010). A SAS is a group of possible strategies and linguistic moves that speakers may employ when performing a speech act. They consist of patterns of output by successful language users in an effort to establish frameworks and options typically employed for specific purposes (for example, to make a request or thank someone). As this study involves EFL learners, English-based SASs have been incorporated; however, SAS patterns may vary by language and culture.

To illustrate, Ishihara and Cohen (2010, p. 8) point out that there are at least five possible options within the speech act set for apologizing: "expression of apology, acknowledgement of responsibility, explanation or account, offer of repair, and promise of non-recurrence." A successful English user would select from these options based on situational factors. SASs may contain obligatory moves (for example, the head act during a request) as well as optional steps (for example, using an attention getter such as "Hi there"). It is important to note that the order of these moves is not always fixed and may vary by situation and/or speaker preference.

The moves for these SASs, based on Ishihara and Cohen (2010) and the University of Minnesota (2014) are displayed in Figure 1.

These formulaic spoken routines offer language teachers practical, research-based archetypes with which to compare their students' output. By using
SASs, instructors can conduct "needs analyses" (Brown, 1995) that can guide instructional decisions and demonstrate pragmatic evolution.

\section{The Study}

Participants in this project were five Japanese second-year university students who studied abroad in the US for one semester. Each had received six years of compulsory EFL instruction in Japanese middle and high schools. They had also completed a required one-year four skills English course at university. In the US, participants stayed with host families and took general L2 and American culture classes at associated universities. In addition, they were involved with volunteer projects within the host community organized through the university. These experiences, along with a variety of personal contacts and interests, likely provided students ample communicative opportunities with interlocutors of various ages and social positions, thereby implicitly raising their pragmatic awareness and ability.

In order to evaluate the usefulness of SASs as (a) instruments for monitoring pragmatic speaking ability of study abroad students and (b) tools for targeting students' pragmatic needs, participants did a set of ten oral discourse completion tasks (ODCTs) based on Taguchi (2014). Each ODCT situation was read aloud by the author while participants read a written version. Participants were allowed to ask for clarification if necessary and then were
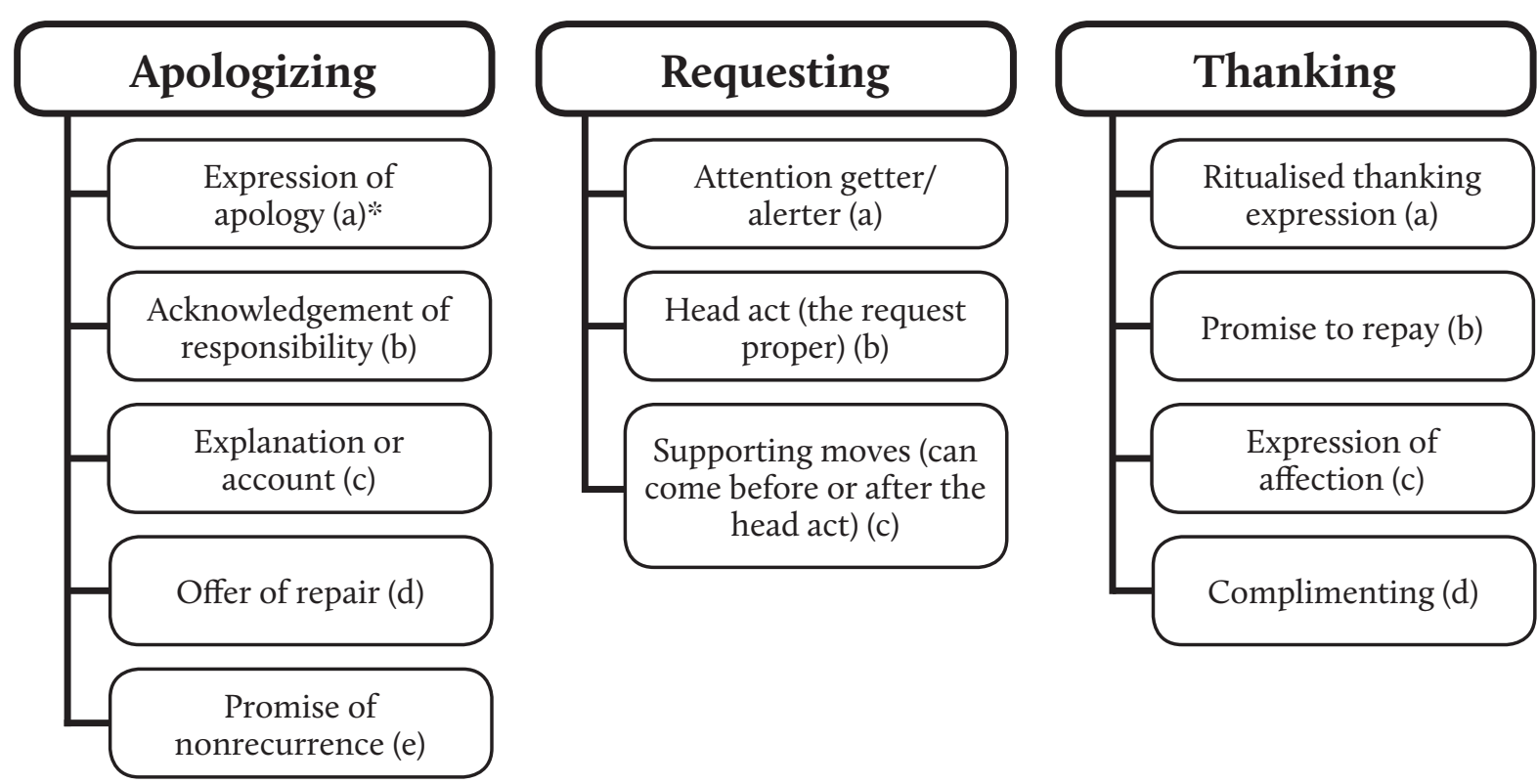

Figure 1. Speech act sets for apology, request and thanking.

*Note: Lower-case letters in parentheses used analysis 
given one minute to think before responding to the prompt. The sessions began with practice ODCTs (as recommended by Ishihara \& Cohen, 2010), took approximately one hour, and were administered by the author.

Using a pre/post-study abroad format, students completed the same set of ODCTs, which were video recorded and transcribed. The transcribed responses were then compared to the standard SASs (described above) to determine which pragmatic steps and strategies learners used to accomplish the tasks. The next section discusses responses to three of those speaking tasks: an apology, a request, and a thanking scenario.

\section{Findings and Discussion}

Data for each pragmatic situation is exemplified through selected extracts, which were chosen because they were generally representative of the entire data set. The participants' spoken output from the ODCTs was compared to the SASs to determine which steps students were able to accomplish and those that may indicate a need for targeted instruction. Findings are presented in Tables 1 to 6. Pseudonyms have been used for participant names. Lower-case letters after each step correspond to the SASs in Figure 1, and the symbol (x) indicates an utterance that does not fit easily into the SAS patterns.

\section{Apology}

Learners responded to the following prompt, which called for an apology:

"You and your friend, Jessica, are working on a class project together. You meet Jessica at a school cafeteria to talk about the project. You forgot to bring your notes that you had promised to bring to the meeting. What do you say to Jessica?"

Through SAS analysis, these extracts from Ann's and Tom's pre/post-study abroad ODCTs show changes in pragmatic ability to apologize.

\section{Table 1. Ann's Apology Output}

\begin{tabular}{|c|c|}
\hline Pre & Post \\
\hline $\begin{array}{l}\text { I'm sorry I forget my } \\
\text { note at my house. } \\
\text { (a) If we have time } \\
\text { for project mm? ah, } \\
\text { meeting I'm sorry } \\
\text { I come back to my } \\
\text { house. (possibly d) }\end{array}$ & $\begin{array}{l}\text { I'm so sorry I left my note } \\
\text { in my house. (a) If you have } \\
\text { time today, I can I back to } \\
\text { my house and bring my } \\
\text { note? (d) Or if you don't } \\
\text { have time, can I change } \\
\text { meeting schedule? (d) }\end{array}$ \\
\hline
\end{tabular}

Table 2. Tom's Apology Output

\begin{tabular}{ll}
\hline \multicolumn{1}{c}{ Pre } & \multicolumn{1}{c}{ Post } \\
\hline $\begin{array}{l}\text { I'm sorry I forget } \\
\text { my notes (a) so }\end{array}$ & $\begin{array}{l}\text { Ah, I forget my notebook. } \\
\text { could you take me }\end{array}$ \\
some notes? (x) & $\begin{array}{l}\text { just a moment, so I go back } \\
\text { to ah classroom last class- } \\
\text { room classroom to get to get } \\
\text { to bring the my notes. (d) l'll } \\
\text { be back soon. (x) }\end{array}$ \\
\hline
\end{tabular}

By comparing these speech samples to the SAS for apologizing, it is clear that the learners are able to accomplish one of the steps easily (expression of apology). Another move (offer of repair) is successfully employed in both participants' post-study abroad responses. However, the other three options in the apology SAS are not attempted (acknowledgement of responsibility, explanation or account and promise of non-reoccurrence). It could be that the learners were aware of these options and chose not to incorporate them, or that they felt the situation did not warrant their use. However, another possibility is that learners are not able and/or not confident enough to attempt them in English. As such, it may be beneficial for teachers to include in study abroad preparation.

Also noteworthy are the two utterances marked (x), which do not fit as smoothly into the apology SAS. In Tom's pre-study abroad output, the utterance "so could you take me some notes?" may be an attempt at a solution to the problem, which would allow the situation to progress. Further, in his post-response, the statement "l'll be back soon" seems an attempt to soften the imposition of delaying the meeting. Therefore, the apology SAS may need to be expanded to include steps such as "attempted solution" and "softening impact."

\section{Request}

The following prompt called for learners to make a request:

"You are doing homework in your host family's house. Your host brother, Ken, is an eight-year-old boy and you often play with him. He is watching $\mathrm{TV}$, and it is very loud. It distracts you from your study. You want Ken to turn down the volume. What do you say to Ken?"

Both Helen's and Tom's responses changed noticeably in terms of utterance length, politeness, and sophistication. 
Table 3. Helen's Request Output

$$
\text { Pre }
$$

Post

Ken (a), can you turn down? (b) It's noisy.

(c) I want to study. (c)

I'm doing my homework now, but I can't focus on that because TV is noisy (c), so would you turn down the volume? (b)
Table 4. Tom's Request Output
Pre

Eh, Ken, (a) I want to study. (c) So the room is too loud, (c) so could you turn down the TV volume? (b)
Post

Ken (a), what what are you watching? (c) It's good, ah so actually, I study I'm studying. (c) I'm doing homework (c) so could you could you turn turn down volume a little bit? (b) I ah after that $\mathrm{l}$, when I finish the homework, ah, I want to watch with you. (c)
These extracts show that participants are able to incorporate all three parts of the request SAS, though to varying degrees. Helen's pre-study abroad request consists of all stages, but several are brief and direct. Her development is evident through her later reply that includes more polite and descriptive statements. Tom also utilized all parts of the SAS both before and after his time abroad. However, in his post-response, he incorporates more supporting moves (c), both before and after the head act (b). His opening gambit, "what are you watching?", is particularly interesting, as he is able to strategically and indirectly address Ken and his TV viewing. Such sophistication was largely absent from all pre-study abroad responses.

This analysis of requests may inform teaching practice in a different way than the apology analysis. For apologies, it was evident that learners were not able to include or were omitting certain parts of the SAS; thus, those steps make clear teaching points. In the case of requests, however, the participants demonstrated the ability to include all three parts: attention getter/alerter, head act, and supporting moves. In order to build on the linguistic and strategic knowledge students have exhibited, teachers may wish to focus on a variety of expressions for the head act (for example, Would you mind...? Or Do you think you could...?) to expand learner choice. Another point of emphasis could be ensuring that learners are able to make a request to a range of interlocutors by adjusting age, position and/or social status in role play situations.

\section{Thanking}

Students also responded to the following thanking scenario:

"You and your close friend, Molly, are taking the same Spanish class. You misplaced your textbook, so you borrowed Molly's textbook over the weekend to do your homework. You return the textbook to Molly on Monday. What do you say to her?"

Below are Sal's and Helen's responses.

Table 5. Sal's Request Output

\begin{tabular}{ll}
\hline \multicolumn{1}{c}{ Pre } & \multicolumn{1}{c}{ Post } \\
\hline $\begin{array}{l}\text { Molly, ah, I could, } \\
\text { I could finish my }\end{array}$ & Oh, oh, this is your text- \\
homework because & didn't borrow me your text- \\
of your help. (c) & book, maybe I would not \\
I'll buy you lunch & I would not do my home- \\
today. (b) & work, (c) so I appreciate it. \\
& (a) Thank you. (a) \\
\hline
\end{tabular}

Table 6. Helen's Request Output

\begin{tabular}{ll}
\hline \multicolumn{1}{c}{ Pre } & \multicolumn{1}{c}{ Post } \\
\hline Thank you for borrow- & Thank you for your \\
ing your textbook. (a) & textbook. (a) \\
\hline
\end{tabular}

Whereas Sal's responses include several of the options from the thanking SAS (e.g., thanking act, promise to repay, and expression of affection), Helen's brief replies are nearly identical and include only the thanking act (a). This analysis offers teachers the opportunity for individualized instruction techniques. Sal has demonstrated the ability to use a number of SAS stages effectively, but may benefit from learning certain nuances within those steps as well as working to eliminate grammatical errors. In Helen's case, instruction that introduces the various strategies and options available for thanking would likely increase her pragmatic range in English.

\section{Limitations}

While these comparisons of ODCT responses and SASs have both displayed pragmatic development and established an itemized catalog of potential teaching aims, both have inherent limitations. As a data collection tool, ODCTs have been criticized for a lack of authenticity and because they are hypothetical rather than natural productions of speech (Taguchi, 2014). Despite these shortcomings, ODCTs were used in this study because they allow the researcher to control social variables and 
generate responses that are relatively convenient to compare and analyse. Weaknesses of SASs include the notion that not all steps are equally important to accomplishing the task and that a single utterance may serve multiple functions (Blum-Kulka \& Olshtain, 1984). Furthermore, the analysis is limited by the fact that speakers may omit one or more of the items in the SAS and thus it is unclear whether participants decided to omit or were unaware of certain options. In addition, as shown through this analysis, there may be some ambiguity about matching utterances to aspects of SASs. However, this study also demonstrates how SASs can provide practical frameworks for evaluating student performance and isolating language and strategies that learners may benefit from, and thus, they can inform instruction. Finally, these findings come from a small number of participants and therefore sample size is a limitation.

\section{Pedagogic Implications and Conclusion}

As illustrated above, SAS analysis can help inform study abroad instruction, ensuring that teachers are targeting areas and functions their students have not yet acquired. It can also aid curriculum planning that aligns with needs analysis principles (Brown, 1995). When patterns of general student performance are identified, such analysis can inform teachers of whole-class needs. In cases where individual student output varies noticeably (as in the thanking examples above), teachers may tailor instruction to meet specific student needs, either by making content more challenging or by emphasizing SAS stages that students may be unaware of or underutilizing. Instructional support for study abroad students can come either prior to or after the study abroad experience, preferably both. The former can prepare learners with rudimentary tools, while the latter can refine and build on what they have gained after returning to their home countries.

Through role play and dialogue activities, teachers can expose students to various relationships and situations, practice which will prepare students for the myriad interactions they will encounter on study abroad. Such activities are staples of study abroad preparation. However, SAS analysis can inform and improve role play and dialogue activities by highlighting the strategies students both use and neglect, which can help teachers pinpoint those areas with which students need the most support. Subsequently, more meaningful instruction can take place. Shively (2010) suggests using recordings of natural conversations, L2 films, and transcripts for pragmatic practice. Likewise, Taguchi (2014, p. 20) recommends "cultural adaptability [and] strategy training" to help students prepare for creating and maximizing opportunities for pragmatic practice. These and other types of pragmatic instruction are accessible to any EFL/ESL educator, either NNS or NS, so long as they have adequate socialization with L2 pragmatic conventions (Kasper \& Rose, 2002).

This paper has demonstrated how viewing study abroad students' responses to ODCTs through SASs can inform instruction. Although the focus was on students who studied overseas, the findings can apply to learners who are planning to travel or live overseas and/or to those who may interact with other users of the L2. Once analysis like that illustrated in this paper has identified linguistic and/or strategic steps that learners need practice with, teachers and curriculum planners can develop tailored and targeted instructional methods. Through informed teaching practices, learners will expand their range of pragmatic choice and exercise that range to achieve intended interpersonal effects,

\section{The Language Teacher needs you!}

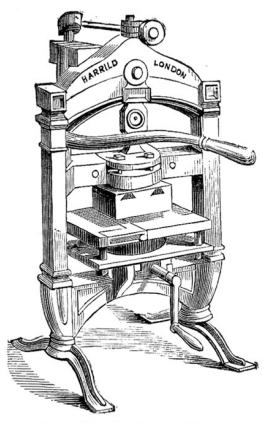

If you are interested in writing and editing, have experience in language education in an Asian context, and are a JALT member, we need your help. TLT is currently recruiting proofreading and editorial staff.

Learn a new skill, help others, strengthen your résumé, and make a difference! If you would like to join our team, please contact the editors: $<$ tlt-editor@jalt-publications.org> 
thereby addressing two cornerstones of pragmatic ability. While the SASs may not account for every single utterance produced during functional communication, they provide practical, accessible archetypes that transfer easily from academic literature to the classroom.

\section{Acknowledgement}

This work was supported by JSPS KAKENHI Grant Number 26770200.

\section{References}

Brown, J. D. (1995). The elements of language curriculum. Boston: Heinle and Heinle.

Byram, M., \& Feng, A. (2006). Living and studying abroad: Research and practice. Clevedon: Multilingual Matters.

Blum-Kulka, S., \& Olshtain, E. (1984). Requests and apologies: A cross-cultural study of realization patterns. Applied Linguistics, 5(3): 196-213.

Crystal, D. (1997). English as a global language. Cambridge: Cambridge University Press.

Fraser, B. (2010). Pragmatic competence: The case of hedging. In G. Kaltenböck, W. Mihatsch, \& S. Schneider (Eds.), Studies in pragmatics 9: New approaches to hedging (pp. 15-35). Bingley: Emerald Group.

Ishihara, N., \& Cohen, A. (2010). Teaching and learning pragmatics: Where language and culture meet. Harlow: Pearson Longman.

Kameda, M. (2013). Education panel touts more global approach. The Japan Times 29 May 2013. Retreived from <http://www.japantimes.co.jp/news/2013/05/29/national/education-panel-touts-more-global-approach/\#. Ve1ZKGSeAXA>

Kasper, G., \& Rose, K. (2002). Pragmatic development in a second language. Malden: Blackwell.

Kinginger, C., \& Farrell, K. (2004). Assessing development of meta-pragmatic awareness in study abroad. Frontiers: The Interdisciplinary Journal of Study Abroad, 10, 19-42.

Mitchell, R., Myles, F., \& Marsden, E. (2013). Second language learning theories. New York: Routledge.

Shively, R. (2010). From the virtual world to the real world: A model for pragmatics instruction for study abroad. Foreign Language Annals, 43(1), 105-137.

Taguchi, N. (2011). The effect of L2 proficiency and study-abroad experience on pragmatic comprehension. Language Learning, 61(3), 904-939.

Taguchi, N. (2014). Cross-cultural adaptability and development of speech act production in study abroad. International Journal of Applied Linguistics doi: 10.1111/ ijal.12073.

University of Minnesota. (2014). Center for Advanced Research on Language Acquisition. Retrieved from <http:// www.carla.umn.edu>
Joseph Siegel is Associate Professor in the Department of International Business at Meiji Gakuin University, where he teaches general and business English courses, as well as study abroad prep classes. He holds a Ph.D. in Applied Linguistics from Aston University and recently published the book Exploring Listening Strategy Instruction

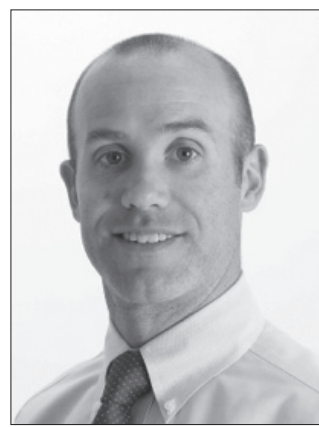
Based Language Teaching in Asia Conference

The JALT Task-Based Learning SIG are proud to sponsor the "3rd Task-Based Language Teaching in Asia" conference, to be held June 25 - 26 2016, at Ryukoku University in Kyoto, Japan. We would like to invite those with an interest in this field to submit an abstract for a paper (25 mins), workshop (40 mins), or poster session, which must not exceed 300 words.

\section{Submission deadline: 15th March 2016}

Please e-mail your abstracts as Microsoft Word attachments to tbltinasia@gmail.com

For more information, go to

http://tblsig.org/conference and for any enquires email tbltinasia@gmail.com

\section{On JALT2014 Conversations Across Borders}

The 2014 Conference Proceedings is now available to JALT members online!

Over 70 papers offering information and ideas to support and motivate you in your learning, teaching, and research. $<$ http://jalt-publications.org/proceedings $>$ 